\title{
THE EDUCATION OF A PRINCE: VATIC SATIRE IN Horace's EPODE 16 and Virgil's ECLOGUE 4
}

\author{
A educação de um príncipe: sátira profética no \\ Epodo 16 de Horácio e na Écloga 4 de Virgílio
}

\author{
Rodney Merrill
}

\begin{abstract}
For two millennia Virgil's Fourth Eclogue has been read as heralding the advent of a marvelous Boy who would solve Rome's problems and give rise to a golden age. Yet on closer consideration, the poem is clearly and entertainingly satirical of such prognostications, educating the audience, especially the young Octavian, as to how illusory they are. This reading is bolstered by a discussion of the historical circumstances surrounding its composition, by comments on others of Virgil's works-Dirae, Eclogues 1 and 9-and by a comparison with Horace's Epode 16, composed about the same time and probably as an effort consciously parallel to Virgil's Eclogue 4. The resemblances between these two poems have often been noted, especially in the "vatic" persona that they both present. No one could doubt the satirical intent of the Epode, in which the prophet counsels Romans to abandon their city for a never-never land where all will be well. Virgil's poem presents a different but no less improbable solution; no one has ever convincingly demonstrated what Boy he might have had in mind, for the good reason that he had none except in a prophetic fantasy. The details of his prophecy move from the barely plausible to the extravagantly ridiculous: a speeded-up recapitulation, in the Boy's lifetime, of several hundred years of history; sheep whose wool changes color in the fields. The
\end{abstract}


poet even satirizes his own pretensions in a passage acclaiming his prospective superiority to the gods of poetry in narrating the hypothetical exploits of his hypothetical Boy. Virgil himself labels this collection Saturae in a transparent but deniable pun in the last line of the tenth and last Eclogue. The whole discussion throws light on Virgil as a poet as skilled in comedy and satire as in the more serious genres with which he usually credited. And it shows that Eclogue 4 is more intelligent, entertaining, and educational as a satire than as the serious prophecy it has been taken to be. Translations of Epode 16 and Eclogue 4 are appended to the article.

Keywords: prophecy, Horace, Virgil.

\section{RESUMO}

Por dois milênios, a quarta bucólica de Virgílio tem sido lida como a anunciação do advento de um Menino maravilhoso que resolveria todos os problemas de Roma e que traria uma nova Era de Ouro. Contudo, considerando mais de perto, o poema é uma sátira clara e divertida dessas expectativas, educando a audiência, especialmente o jovem Otaviano, quanto a seu caráter ilusório. Esta leitura é motivada por uma discussão das circunstâncias históricas em torno da composição, por comentários sobre outras obras de Virgílio-Dirae, Bucólicas 1 e 9-e pela comparação com o epodo 16 de Horácio, composto por volta do mesmo período e possivelmente um esforço conscientemente similar à quarta bucólica. As semelhanças entre os dois poemas foram apontadas frequentemente, especialmente na persona 'vática' que ambos apresentam. Ninguém poderia duvidar do objetivo satírico do epodo, no qual o profeta aconselha os romanos a abandonar a cidade em busca de uma terra-do-nunca onde tudo estaria sempre bem. O poema de Virgílio apresenta uma solução diferente mas não menos improvável; ninguém demonstrou de modo convincente quem seria o Menino que ele teria em mente pela simples razão de que ele não tinha nenhum, a não ser uma fantasia profética. Os detalhes da profecia vão do quase plausível ao ridículo e extravagante: uma recapitulação acelerada de centenas de anos de história durante a vida do Menino, ovelhas cuja lã muda de cor nos campos. O poeta satiriza até mesmo suas próprias pretensões em uma passagem que proclama sua superioridade aos próprios deuses da poesia ao narrar os feitos hipotéticos do Menino hipotético. O próprio Virgílio intitula sua coleção de Saturae em um trocadilho transparente mas negável no último verso da última bucólica. Toda a discussão lança luz em Virgílio como um poeta versado não somente nos gêneros elevados 
que compôs mais frequentemente, mas também em comédia e sátira. além de mostrar que a quarta bucólica é mais inteligente, divertida e educativa como sátira do que do que como a profecia séria que se considerou que fosse. Acrescentamos em apêndice traduções para o inglês do Epodo 16 e da Écloga 4.

Palavras-chave: profecia, Virgílio, Horácio.

In the last verses of Epode 16, Horace asserts that a fortunate escape from the bronze and then iron to which Jupiter has hardened the ages is offered to the righteous by himself as vates, prophet-bard:

... [Iuppiter] duravit saecula, quorum

piis secunda vate me datur fuga.

... Jupiter] hardened the ages; from them is a lucky escape vouchsafed the righteous by a prophet-me.

$$
\text { (Ll. 65-66. }{ }^{1} \text { ) }
$$

With this affirmation of prophetic power he concludes his proposal that the Romans, or rather the better part of them, escape the civil wars by taking ship for foreign parts where they will find an ideal country reserved for the righteous. Without labeling himself so explicitly, Virgil makes the same claim to vatic authority in his famous fourth eclogue, which prophesies the imminent birth of a divine Boy bringing an age of gold. Only the most naïve reader - one who could also think that Jonathan Swift meant just what he said in $A$ Modest Proposal for ameliorating Irish hunger and poverty by raising the infants of the poor to be roasts for the rich-could believe that the "prophet" Horace was serious in advocating the abandonment of Rome for a never-never-land Elsewhere. But Virgil's claim has been taken at face value for centuries and up to the present: he was really making a prophecy of better things ahead. Many Christians, including Constantine the Great and St. Augustine, believed that the poem foretold the coming of the Messiah (VIRGIL, Eclogues, ed. Coleman, p.152), and a popular medieval English religious pageant, the First Shepherd's Play, quotes 11. 6-7 (in reverse order) as prophecies of Christ's coming (CAWLEY, 1958, p.39 and note, p.103). In his Advertisement to his Messiah, Alexander Pope notices the eclogue's 
similarities with the prophecies of Isaiah and assumes that Virgil was seeking to convey in pastoral poetry the prophecies of the Sybil concerning the same sort of advent as that of Christ (POPE, p.189). Samuel Johnson sees it as a serious attempt, "filled with images at once splendid and pleasing," even in his puzzlement about what he calls "the disproportion between the performance and the occasion that produced it: that the golden age should return because Pollio had a son, appears so wild a fiction, that I am ready to suspect the poet of having written, for some other purpose, what he took this opportunity of producing to the public" (JOHNSON, Adventurer 92). Johnson's perplexity evidently arises from his literary acumen-indeed, I hope to show what "other purpose" the poem might have served. The same sorts of perplexity appear in others; Paul Alpers (1979, p.156-183) finds the attempt to reconcile the grand style of the poem with pastoral simplicities a problem, which he solves by attributing to Virgil an extraordinarily subtle-and by the same token, imperceptible to the common reader-poetic genius. Other scholars and critics still take for granted the seriousness of the prophecy, even when they cannot understand why it was written: Wendell Clausen remarks in introducing the poem (VIRGIL, Clausen ed. 1994, p.119), "Why Virgil took notice of the Sibyl's annunciation, which would otherwise be unknown, and made it the pretext for a poem - a beautiful, mysterious poem-we can only guess." Like Alpers (e.g., "the child is mythical or symbolic," 179), Robert Coleman asserts in his Commentary (52), "The child is for Vergil a symbol of the divine forces that will bring the nouum seculum to pass."

The epode and the eclogue have enough points of resemblance that critics have often noticed them. In addition to their similar modes of addressing the reader mentioned above-presenting themselves as prophets-both assume a powerful desire to leave behind the miseries of the present, and they share some features of an ideal landscape which their listeners may anticipate, whether in the land to which Horace's fellow citizens can flee after abandoning Rome or in the future that Virgil predicts. In one detail their correspondence seems especially significant: both of them cite the voyage of the Argonauts as an example of the evils respectively of the iron age or of the "bad old days"-Horace's prophet says (1. 57f.) that it will not happen in the new land the escapees will find, Virgil's prophet (1. 84) that it will recur before the final maturity of the wonderful Boy.

Here I want to suggest that such resemblances would not be surprising, if the two poets were familiar with each other's project, so that their poems might have been a sort of collaboration or, better, mutual emulation, coming at the same subject from different angles. No real profit arises supposing that one must have imitated the other, as with regard to the she-goats coming home of themselves with full udders (HORACE, 1. 49f., 
VIRGIL, 1. 21f.) and arguing about which was first, despite commentators who have worried the subject (see Clausen's commentary, p.145-150, for such a discussion). One can as easily imagine the two young poets-who both had strong farm connections-exchanging jokes on this detail of the pastoral life, which they may have thought amusing in Theokritos, Idyll $11,11.12-13$, where this self-motivated homeward return is attributed to Polyphemos's sheep and occasioned by their master's preoccupation with his love for Galatea. They might even have agreed to use it satirically in their respective works. As to the time of composition, the dates of the poets' residence in Rome and the references to current events suggest sometime between 41 and $38 \mathrm{BCE}$. Even though Horace is thought to have published the Epodes in $29 \mathrm{BCE}$, this epode refers so explicitly to a second generation or age still suffering the civil wars that it must have been written earlier, for by 29 , Octavian was master of the Empire and the civil wars were largely over. Paul Shorey, Horace's editor, puts the epode in 41, when the 23-year-old Horace (born Dec. 8, 65,) had returned to Rome from Athens, where he had gone to study Greek (HORACE, ed. Shorey 1919, p.504). This comes close to the putative date of Virgil's Eclogue IV, which refers to the consulship of Pollio in $40 \mathrm{BCE}$ as occurring now or in the near future, when the wonderful events will take place. Horace must have met the 29-year-old Virgil then or soon thereafter, for in about 39 or 38 Virgil introduced him to the circle of Maecenas. (This date is inferred from references in Satire II.VI; see Fairclough's introduction in his Loeb edition of the Satires, p.208-209.) Two young poets inhabiting the same milieu would no doubt have become well acquainted quickly. Moreover, in 41 they and their families had suffered the loss of their farms in the expropriations that Octavian ordered to provide land for the soldiers who had fought for him and Antony at Philippi.

The case for such complementary emulation may seem more plausible after we have looked at the poems themselves. Nevertheless, each can be understood without reference to the other. But keeping in mind the events of the time can contribute much to our comprehension, for both works speak to a historical moment that has had great consequences for the course of the western world. The major events of these years are among the best known of antiquity, especially as Shakespeare has presented them in Julius Caesar and Antony and Cleopatra. My aim here is simply to recall them briefly and put these poets and their poems in that context.

By the time the poets were old enough to be aware of what was happening abroad, the Roman state had been engaged in fierce and disruptive civil wars for some time. The civil war that Horace might have thought of as that of the first age or generation (prima aetas - he speaks of altera aetas in Epode 16.1) was the prolonged conflict mainly between Gnaius Pompeius 
Magnus and Julius Caesar; the second came in the equally bitter hostilities between partisans of the old Republican order, the patrician Optimates, and the supporters of Caesar and his successors Mark Antony and Octavian, many of whom were plebeians - Caesar was "the people's dictator." Other major protagonists in the wars were Marcus Aemilius Lepidus, another supporter of Julius Caesar, and Sextus Pompeius, the son of Pompeius Magnus, who conducted his opposition to the Caesarians from a base in Sicily. Probably underlying the conflict was the vast empire's need for a strong executive, which contradicted the hallowed tradition of the Republic, over four and a half centuries old, by which the patricians, via the Senate and the consuls, and the plebeians, via the Concilium Plebis and the tribunes, shared authority. This clash reached a climax in the assassination of Julius Caesar on the Ides of March, 44 BCE. His successes in war were well known through his own writings, he had been made dictator for life just before his assassination, and many patricians were convinced that he coveted royal status. Therefore a group of Liberators, led by Cassius and Marcus Junius Brutus - the latter of whom was, or considered himself to be, a scion of the Lucius Junius Brutus who had led the expulsion of the last king, Tarquinius Superbus, and founded the Roman Republic - sought to defend republican liberty by eliminating a potential tyrant. Mark Antony, Caesar's lieutenant and would-be heir, was at first conciliatory, but fell out with the Liberators. In fact Caesar had adopted Octavian, his then eighteen-year-old grandnephew (he was born in $63 \mathrm{BCE}$ ) as his son and heir. A conflict was inevitable, but after a preliminary defeat of Antony, in November 43 the two rivals set up a triumvirate with Lepidus as the third, divided the empire, and took responsibility for making laws, causing the Council of Plebeians to ratify the new arrangements in the Forum, as troops oversaw the proceedings.

As a result of this agreement, the three drew up a list of proscriptions against Caesar's enemies and their own-about 300 senators and 2000 equites, "knights"-including Marcus Tullius Cicero, the most prominent senator, orator, writer, and thinker of his time. He had incurred Antony's wrath by speaking forcibly against him in his Philippics, hoping that Octavian would prevail in the conflict. Yet that youthful prince agreed to his condemnation. In December 43, as he belatedly attempted to escape, he was caught and decapitated, and his head was nailed on the rostrum in the Forum along with the hands that had written the Philippics. In October 23, 42, at Philippi in Macedonia, Octavian and Antony defeated the Republican forces under Cassius and Brutus, Cicero's close friend and intellectual peer, and the two leaders committed suicide.

As readers of Shakespeare know, the alliance did not last long; eventually Lepidus was pushed out, and Octavian controlled the western 
part of the Empire, while Antony took the East, and in a naval battle near Actium, on September 2, 31 BCE, Octavian's forces routed Antony's. But for the present, Octavian rewarded the veterans of Philippi with land expropriated from Italian farmers, many of whose families had worked it for generations. Antony formed an alliance with Cleopatra of Egypt and spent the winter of 41-40 with her. She bore him twins; her son by Caesar, Ptolemy Caesar, or Caesarion, was four years old. Even so, the two rivals patched up their differences by the treaty of Brundisium in September, 40. Many commentators see this pact as the occasion of Virgil's Eclogue 4, especially in the reference, 1. 17, to a world pacified, since Pollio, who is addressed in the poem as holding the consulship either now or in the near future, helped arrange the meeting. Antony sealed the pact by marrying Octavian's sister, Octavia, and spent much of 40-36 with her; she too became pregnant by him-with a daughter, as it turned out.

These events must have had a powerful effect on the two aspiring poets. For one thing, the fate of Cicero and others of the highest social orders must have made the active public life in which many leading intellectuals had participated seem both risky and futile, especially with the repression of political activity and the severe censorship under the Triumvirate. At the same time, they must have been moved to sorrow and indignation by the loss of such men as Cicero and Brutus, as well as the poet Cinna, who was killed by a Roman mob that mistook him for one of the assassins; so they might well have been inclined to exercise their literary powers critically. But these brutal events and the repression of free speech, already noticed by Cicero in 46 (in his essay Brutus, dedicated to the future Liberator), and intensified after Philippi, would have recommended caution in voicing that criticism openly and directly. They might have been even more careful in exposing it to the young prince, Octavian, who, Suetonius tells us (Life of Augustus, chapters 10-15), was unsparing in his cruelty to his enemies and even to some of his allies. Nor would it be wise to cross the older lord, Antony, who was equally callous and even more practiced in dealing with anyone he thought might be an enemy. Any criticism would have to be expressed in ways that did not arouse the rulers' anger.

On the other hand, the young poets were placed well to get the young prince's ear, since both had Maecenas as patron, as did other talented poets. This Etruscan aristocrat was about the same age as Virgil (both born in 70), five years older than Horace, seven years older than Octavian himself, whose friend, counselor, and diplomatic agent he became. Equally important for our investigation is the fact that later writers credited him with converting the prince to a more liberal and humane outlook. Suetonius tells us (Ch. 89) 
that Augustus, himself a writer and poet (of a hexameter poem called Sicily), "gave every encouragement to the men of talent of his own age, listening with courtesy and interest to their readings." So Maecenas and his group of poets could hope that works of a cautiously critical and moderating kind might have a real effect on policy if they were entertaining and improving. Indeed, such efforts could have been part of an overall strategy for "civilizing" Octavian, fitting him to be ruler of a great empire.

As mentioned above, the two young poets shared something else: in $41 \mathrm{BCE}$, Octavian or his agents had ordered the expropriation of their family farms, among many others, to reward the soldiers who fought for him and Antony at Philippi. Some believe that Virgil's (or his father's) farm near Mantua was restored through the intercession of his powerful friends, among them Maecenas. Whether or not this happened, such cruel and arbitrary transfer of property comes up as a matter of sorrow and shame in an early poem of Virgil, Dirae, in two of his Eclogues, 1 and 9, and in the second satire of Book 2 of Horace's Satires. Looking at them can suggest how the youthful poets dealt with contemporary injustices, tempering and disguising criticism by including other kinds of subject matter.

The authorship of the poem known as Dirae, like others of the so-called Appendix Vergiliana, has been disputed, but whether or not it is Virgil's, it expresses in direct and unequivocal terms the strong emotions of the dispossessed farmers, and therefore provides a point of comparison with the more cautious criticisms of the other poems. In it the author, whom I will call Virgil, recalls his songs and those of another poet, Battarus (otherwise unknown-probably a fiction), which cursed the land from which they have been expelled by a soldier he calls Lycurgus. Instead of competing in their songs, as do the shepherds in some Theocritean idylls, they cooperate; their alternating maledictions would bring upon the new owner barren soil, wilted crops, immature fruit, blasting heat, dying woods, terrible windstorms, fires, floods both from the sea and from the inland stream - the whole litany of curses amounts to a sort of anti-pastoral. The unsparing ingenuity of these imprecations results in a virtuosic and entertaining balance between the pathos of loss and comically obsessive revenge-fantasies, as the poets briefly evoke the beauty of the landscape as it has been and ought to be-with a lovely girl, Lydia, present in it - and describe more extensively its desolation as the poets envision it in their imprecations. It ends with a protracted and pathetic farewell, as the poet enacts his departure.

Before that, however, in four concentrated lines, 82-85, Virgil expresses his severe judgment on what happened to cause this misery: 


\begin{abstract}
O male devoti praetorum crimine agelli, tuque inimica pii semper Discordia civis: exsul ego indemnatus egens mea rura reliqui, miles ut accipiat funesti praemia belli.

o little farmlands, wrongly accursed by the crime of the praetors, you too, Discord, the foe of the righteous citizen always, uncondemned and in need, my farm I have left as an exile so that a soldier may get his wages for ruinous warfare.
\end{abstract}

Let us suppose with Jean Hubaux (Les Thèmes Bucoliques, Bruxelles, 1930, p.35-65; cited Virgil, Aeneid 7-12, The Minor Poems, ed. H. R. Fairclough, 531) that the ancient critics, Donatus and Servius, were right in attributing this poem to Virgil despite its absence from the major manuscripts of his poetry, and that it is the product of the young poet's indignation over the confiscations of $41 \mathrm{BCE}$. It is easy to understand, after the lethal proscriptions of 43 , why he would not be eager to be identified as the author of a poem that labels as crime the confiscatory acts of the praetors, provincial governors, who were responding directly to the central authority-i.e., Octavian himself. (It is true that crimen can mean "judicial decision," but indemnatus, uncondemned, two lines later, implies strongly that nothing of a judicial sort has taken place, so the sense comes closer to "crime, offence.") No wonder, then, that it does not occur in the major manuscripts of Virgil's poetry. The final line of the passage implies a hardly less provocative criticism of war, presumably that of Octavian and Antony against the republican forces.

But if this poem seemed risky, the poetic talent it manifests could be turned to a less antagonistic and more persuasive use, and Virgil's first eclogue could have resulted from such an intention. It presents a dialogue between two shepherds, one of whom, Meliboeus, has been deprived of his land and is about to leave the country, while the second, Tityrus, has just come back from the city of Rome, where, he says, he went to acquire his freedom and saw a youth who granted him his desire. Meliboeus himself draws the contrast between the two shepherds in his first lines, and after Tityrus attributes his good fortune to a god to whom he will often sacrifice a lamb, the first laments the confusion and turmoil everywhere in the country, his own sickness, and the twin lambs which his ewe has left behind on bare rock to follow him into exile. The full indictment of Octavian's policy, however, comes much later in the poem. Before that, in response to Meliboeus' question who the god was, Tityrus speaks about the greatness of the city, Rome. He went there, he says, because in advanced years he had finally managed to think of gaining his liberty, since when he was with Galatea he took no care 
of it but simply labored for inadequate earnings. But now she has left him and Amaryllis has him; apparently his new woman is less of a spendthrift, so he had been able to save money to get out of servitude (exire servitio). Only in the city, he says, could he have found a divine being to grant him liberty; for it was there that the youth dwells for whom twelve times a year the altars smoke. Indeed he received a response - almost an oracle - allowing him (and others) to continue pasturing cattle and rearing bulls. In a beautiful passage felicitating his friend, Meliboeus evokes the realities of country life-the work in clearing rock or filling marshes, the possibility (though put in negative terms) of invasive fodder and animal diseases, and the pleasures of bees, of slumbering in the fields, of singing birds. Tityrus again affirms his devotion to the divine youth: before he loses the image in his heart, such impossible things (adynata) as stags grazing on the air, the sea leaving fish naked on the seashore, or Parthians and Germans exiled, each to the other side of the empire, will take place. As if in response to these "impossible" exiles we get the full weight of Meliboeus' lamentation, speaking of the distant places of exile to which the expropriated farmers might have to go, south, north, east, and west respectively: Africa, Scythia, the Oxus River (the Amu Darya, in central Asia) or even as far as Britain. He wonders if he will ever see his modest holding again, and exclaims as a climax (70-72):

impius haec tam culta novalia miles habebit, barbarus has segetes. en quo Discordia civis produxit miseros: his nos consevimus agros! Fallow so well cultivated a godless soldier will hold, some stranger will have these crops! See how such Discord has brought forth miserable citizens_-our lands we planted for such men!

This is a strong rebuke, even if short, and sharpened especially by the use of the pregnant words civis and agros: the cruel confiscations affect not just countrymen, but the citizenry, and ager can mean not only farm, but territory or district, as in ager Romanus. Meliboeus continues to contrast the pleasant state of his friend with his own misery, especially addressing his goats as deprived of their right livelihood. And Tityrus drives home the contrast by offering his friend a night's hospitality with good food.

In effect, this eclogue is a sort of Mirror for Magistrates. It offers the divine youth in Rome-Octavian, then in his early twenties, who was styling himself divi filius, son of god, since his adoptive father had been declared divine by the Senate, and who as such was probably offered monthly sacrifices-alternate ways of presenting himself to his citizenry, as a cruel expropriator of ancestral property, or as a just and merciful agent of the 
citizens' prosperity. The "lesson" would fit well with Maecenas's efforts to educate the youthful prince, who might well have learned from its gentle but pointed admonition. For as Augustus he would cultivate his reputation for justice and respect for ancestral traditions.

Moreover, this lesson has general relevance in several directions. Though it refers to real events in Italy, it applies to all relations between a ruler and his subjects, whatever the domain. Nor is it limited to Rome, nor to supreme rulers, nor to this specific point in time. Anyone in a position of authority should consider the same alternatives, whether to be known as a tyrant or as just and attentive to his subjects' legitimate needs and desires. This idea is hardly new, but it is made effective here by the pathos portrayed on the one hand and the contentment on the other. The bucolic setting adds to the pathos, emphasizing the miseries of the most powerless people. It also provides an entertaining fiction that brings the reader's mind into activity as he tries to "figure out" just what it means. To that end Virgil includes some puzzles. In particular, it is not at all clear why a slave would have gone - or indeed, been allowed to go - to Rome to gain his freedom. Ordinarily, after accumulating the necessary money, he would pay it to his master, who would grant manumission by touching him with a liberating rod, the vindicta, in the presence of a nearby magistrate, probably the provincial governor, the praetor. So why would Tityrus have taken such an ambitious trip? Clausen's remark (p. 31, 43) that "Libertas" was the slogan of Octavian and his party and thus Virgil confuses personal and public liberty does not solve this puzzle, though it does enrich it. We still do not know how or why a person in servitium, slavery, would travel to Rome to leave it, exire. In fact when he does encounter the youth whose praises he will never stop sounding, nothing is said about freedom-as T. E. Page notes (97), "line 45 [the reply of the divine youth he has addressed, "pascite ut ante boves, pueri; summittite tauros"] is an absurd answer to Tityrus seeking for freedom." It addresses plural supplicants, pueri; as a remedy it applies entirely to the predicament of the dispossessed and exiled Meliboeus, the representative of a large number of farmers, rather than to that of Tityrus the slave. And that is the point Virgil makes, or rather causes the reader to make: this is the sort of power the prince has. Thus, though the young prince in Rome may have his vanity stroked by Tityrus's adulation, he should see that such praise must be earned by actions different from some of those he has performed, which violated ancestral property and civil propriety.

A similar "message" emerges from Eclogue 9, in which the rustic poet Moeris laments the loss of his farm to an outsider and the inability of mere poetry to resist such injustice. He even points to greater violence, the probable death of himself and his friend, the poet Menalcas, if he had not 
been warned by a raven in an oak tree to stop a quarrel. Moeris might be alluding to Virgil's conflict, almost resulting in his death, with the centurion Arrius, to whom his (or his father's) farm near Mantua had been assigned (Page, p.139). But it hardly matters; the rather vague allusion is probably safer than an explicit description of a brutal soldier who would not hesitate to kill the farmer who resisted being expelled from his ancestral holdings, thus underlining the recklessness of the prince who instituted the expropriations. In case the reference should be not be clear enough, Moeris soon quotes from a poem Menalcas wrote for Varus, "Mantua vae miserae nimium vicina Cremonae," "Mantua, woe's me, is far too close to unhappy Cremona," the latter city being the epicenter of the expropriations in Northern Italy. Again, however, the reader must make the connection. Still later the other shepherd, Lycidas, says that the shepherds call him, like Menalcas, a vates (1. 34), and mentions Cinna and Varius as poets he cannot equal, the first being the poet Cinna who was killed in the aftermath of Caesar's assassination - another veiled allusion to the violence of the age.

We hear Menalcas's prophetic voice a few lines later, when Lycidas quotes his song about the star of Dionean Caesar rising. Dione bore Aphrodite/ Venus to Zeus/Jupiter; Venus's son Aeneas (whom she bore to Anchises the Trojan) was the mythical founder of the Julian clan of which Octavian was now the leading member (Coleman 266-67) - he claims descent from both Jupiter and Venus. This star will cause the grain-fields to rejoice in their crops and bring ripeness to the grapes on the sunny hillsides. So Daphnis should graft his pears, for his grandsons will pick the fruit.

More than simple flattery of Octavian, this "prophetic song" seems like Eclogue 1 to derive its significance from the political context, as it offers for the ascendancy of the Julians a policy more desirable than that of the expropriations inflicted on Moeris and Menalcas by the "divi filius" and his soldiers. Again, a gentle nudge in the right direction might be more effective than an open attack in making the prince recognize that a wiser course of action would enable grandsons to pick the fruit their grandfathers started and thereby make citizens celebrate the rise of the Julian star instead of cursing it for the civil convulsions and confiscations it occasioned.

Both these eclogues, then, advance in fictional terms a fairly severe criticism of recent acts while recommending another kind of policy that would bring more credit. This reading hardly exhausts the poetic wealth of these works, but the other features of Virgil's art have received ample discussion. To conclude this introductory section, I will briefly discuss Horace's handling of these expropriations, in the second of Book 2 of his Satires. This poem tells us in the first line that it will advance the virtue of frugal, or even cheap, living (vivere parvo) as the peasant philosopher Ofellus taught it to the poet. Indeed, 
it recommends a plain diet, and in so doing satirizes the luxurious diets of the wealthy in considerable amusing detail-food following fashion more than real appetite, food favored for its exoticism rather than its excellence. This part of the satire must have appealed strongly to Octavian: Suetonius (Ch. 76-77) tells us that he preferred simple fare and was sparing in his use of wine. On the other hand, says Ofellus, one should live generously, not meanly - again, Octavian was fond of dinner parties, though according to Suetonius he often ate his simple victuals beforehand and abstained from eating the rich banquet food. This simplicity of life will bring health, says Ofellus, and will allow more indulgence on special occasions and in ill-health or old age, as well as entertainment of friends when they visit. Only at the end do we learn that Ofellus, the exemplar of this frugal but balanced life, is one of the expropriated. He has made a virtue of necessity in accepting his sad lot and advancing from it to philosophical reflections on the vicissitudes of fortune: Now the farm goes by the name of Umbrenus, lately it bore that of Ofellus, but it will belong to no one forever. Therefore live as steadfast men, and oppose steadfast hearts to the strokes of adversity.

Horace's approach is even more oblique than Virgil's: he wants to exemplify the superior worth of those whom Octavian's policy has callously evicted from their lands, thereby possibly implanting in him some remorse at what he has done, as he contemplates this rustic but thoughtful representative of traditional Roman virtue, especially the frugality he himself prizes. How much better to have such people on the land, he might think, than men like Umbrenus who have driven them out and have no real claim to the farm.

I have looked at these poems to suggest how their poets, at least in these works, are immediately engaged in a pragmatic, and very Roman, attempt to reform attitudes even on the political level. In the two major poems under discussion, this concern is operating at least as strongly, though the "message" is not so narrowly focused on the actions of the prince himself. (See my translations appended to the article for references.) This broader relevance clearly appears in what seems the most obvious case, Horace's Epode 16, which powerfully evokes the historical situation outlined at the beginning, especially the horrors of the civil war. In this new generation the Romans themselves are achieving by their own strength a ruination that the Marsians, the Etruscans under Porsena, Spartacus, the Gaul Allobrox, the wild Germans, or Hannibal could not accomplish, returning the land to the beasts of prey and desecrating the city (1-14). The speaker could hardly emphasize more strongly who is to blame: "We will destroy her, an impious, cursèd-of-blood generation." Then he turns to the desire either by all in common or by the "better sort" (an important qualification, it will turn 
out), to escape such evil sufferings, malis laboribus. He models his proposal on the Phocaeans in Greece, who "cursed their country and / gods of their fathers, abandoning these and their shrines to the bears and / rapacious wolves to make their lairs in, took to flight." (11. 18-20) It is worth noting that the Phocaeans could be celebrated as heroic devotees of liberty for having decided to abandon their city rather than submit to Harpagus, the general of Persian King Cyrus (HORACE, ed. Shorey, p.506; HERODOTOS, 1.165). But Horace presents them in unflattering terms as having consummated what the impious present generation of Romans seems intent on doing: ruining their city.

So when he says that the Romans, or the better among them, must follow the example of the Phocaeans-go wherever our feet or the winds blowing our ships take us - we wonder how he can justify such radical action. As if in reply to our questioning, he turns to his listeners and challenges them to give better advice (1.23). But, apparently assuming no such advice is on offer, "Horace" goes on in an extensive passage to propose oaths that there shall be no return, no sweet homecoming, until several impossible things (again, adynata, as in Eclogue 1) shall have taken place: rocks rising from the ocean and swimming, the river Po washing the peak of Mount Matinus, the Apennines jutting into the sea, monsters joining in unnatural desiretiger with deer, dove with kite - the credulous herd not fearing the lion, the goat turning scaly smooth and loving the briny sea. What can be the point of such repeated emphasis on adynata to confirm an oath? Most obviously, it suggests how strong will become the desire to return home almost as soon as home has been abandoned. Beyond that, it could be a caustic if indirect comment on the incessant breaking of oaths of loyalty and alliance that have led to the ruination of the Roman state and its citizens. It is as if Horace - the real one-is asking, Is there any oath at all that can make our rulers hold to their promises? But he cannot ask it directly: to do so, as I have suggested, may be dangerous, and moreover the point is made more effectively in a sort of riddle. When he goes on to say that only the better part should go; the unteachable herd, the feeble and hopeless, can "stay ensconced within their ill-starred beds," the irony suggests another failing of the rulers: they have neglected their duties to the lower orders, so they may go on doing so when they abandon the city altogether.

The next section begins with an extremely ironic reference to "virtus," manly strength, which now is to be shown in abandoning the city, not defending it, and seeking for arva beata, divitis insulas - "the happy fields, the wealthy Islands of the Blest." Then comes the catalogue of wonders which these valiant fugitives will encounter, often resembling those that, as we shall see, "Virgil" in Eclogue 4 predicts for the future. Whereas the fields 
simply turn yellow in the eclogue, here they yield their grain unplowed; there are no clusters of grapes on brambles here, but the vines flower without pruning. Otherwise, his predictions make this new land sound like a slight improvement on the Italian countryside, with olives that never fail to bud and dark figs that decorate their own trees. Honey here is not sweat to be scraped off of the oak's bark, as in Eclogue 4; rather it flows, perhaps in larger quantities, from the hollow ilex tree-not too unlike Roman beehives! And the water that comes from the high mountains probably resembles that of Rome, too. The she-goats come to the milk-pail unbidden and bring back swollen udders, as they customarily do in the country-Virgil tells us so in his Georgics, 3.316-317, when he is describing how convenient and profitable it is to raise goats. The lines are worth quoting to bring out the full banality of this "wonder":

atque ipsae (sc. capellae) memores redeunt in tecta, suosque ducunt, et gravido superant vix ubere limen.

Minding themselves they return right into their folds, and they lead their kids, and for weight of their udders can hardly get over the threshold.

Here we see clearly why the she-goats return without urging, quite aside from the habits inculcated from birth - their heavy udders need milking to prevent severe pain, and that happens back at the fold. By including this feat among the marvels of the happy land, Horace the farm boy pokes fun at city-slickers who do not understand how things work in the country. (You can almost hear a visitor from the city to Horace's farm exclaiming, "Ecce capellae venientes, nemine agente!" "Here come your she-goats—and nobody is driving them!") He finishes this list of the wonders of that blessed land by noting that bears and vipers are well under control-as they are in Roman territory, or at least as they would be if the civil wars had not led to such negligence that wild beasts could be envisioned as taking over the city itself.

But if we are to have all of the comforts of home, there are greater advantages as well, not to be found in any part of the known world-never so much rain that the fields are scraped away, no drought to burn up the seed. And there is no pine straining with Argonaut-oarsmen, nor does a shameless Colchian woman (Medea) set her foot there, nor Sidonian sailors turn their spars there, nor the much-enduring crew of Ulysses. No contagion harms the flock, nobody's herd burns under the violent fury of a malignant star. True impossibilities, these, as any reader recognizes-human nature cannot be so easily changed as to prevent traveling, trading for wealth, or witchcraft, and the weather will remain unpredictably good and bad until 
the end of time.

The poem concludes in savage irony with the prophet's complacent assertion that "Jupiter put these shores in reserve for a race of the righteous" when "he befouled the age of gold with bronze" and hardened the ages, from which escape is vouchsafed the righteous by a prophet, himself. Calling "righteous" a generation characterized a few lines ago as impious and bloodcursed, which now is to add abandonment of the city to its ruinous impiety, ironically emphasizes how craven and contemptible is the "solution" they are offered-and suggests further how craven the "better" Romans already are, as long as they do not mobilize their wits and strength to defend and rebuild their home.

Such is Horatian satire-not outright invective, but no whit the less telling. Virgil's Eclogae, Eclogues, can be equally oblique in their criticisms, as we have seen with respect to the first and the ninth one. The pastoral setting of many of them has made the title of the collection-which in fact has the neutral meaning of "selections"-one of the chief ways of labeling later poetry of this genre or mode. Ovid calls them Bucolici modi (Tristia 2.538, cited in Page's edition of Virgil, $\mathrm{x}$, footnote 1), referring to the stylized rusticity of the cowherds, shepherds, and goatherds who are the chief characters and singers. The "pastoral" genre derives from the Greek "bucolic poets" of Hellenistic times, especially Theokritos, who lived two centuries before Virgil. But we have seen that the pastoral in at least two of these Eclogues is incidental to the main theme, a way of presenting a major issue attractively and indirectly. Others imitate Theokritos in various ways, including singing contests and exchanges of abuse between herdsmen. But they are not all pastoral poems, and the Fourth Eclogue in particular has little claim to the bucolic; it is a prophecy that ranges far more widely than the countryside.

In fact Virgil himself, in an ingenious but deniable pun, says quite clearly to what genre he thinks this collection belongs. The last line of the tenth and last eclogue reads as follows:

Ite domum saturae, venit Hesperus, ite capellae.

The word saturae has always been taken as an adjective, "well-fed," modifying capellae, "she-goats." But no well-read contemporary of Virgil could have failed to read the first short but complete clause of the line as an address to the saturae - a noun, the feminine plural vocative case of saturathe satires, that constitute the collection. Some of the best-known literary productions of the preceding age were the thirty books of Saturae by the poet Lucilius, whom, as we know from references in his works, Horace regarded 
as his great progenitor, though like Virgil he avoided calling the poems we call Satires by that name-they were Sermones, Conversations. That Virgil himself had read Lucilius we know not only from the overwhelming probability that any cultivated Roman would have done so, but also from a direct quotation in Eclogue 8.63, "non omnia possumus omnes," from Lucilius's Book 5, as noted by Macrobius (WARMINGTON, v. 3, 76.) Indeed, Roman literati, as represented by the great critic Quintilian, regarded the satura as a purely Roman creation, Rome's greatest contribution to literary genres (HORACE, Fairclough ed., Satires and Epistles, xiv). Unfortunately, the abundant and celebrated works of Lucilius, who lived c. 180-103 BCE, exist only in fragments - around 1300 isolated lines remain to us, and they are hardly known to most readers of the classics-so we cannot respond to this noun as a literate Roman would have.

It is true that when we get to the end of the line, capellae can cause us to add the adjectival meaning, "well-fed," to the final complete clause, especially in view of line 30 above, "nec cytiso saturantur apes, nec fronde capellae," "neither are bees satiated with clover, nor she-goats with leafage." But doing so does not cancel the former sense, especially since the repeated ite, together with the intervening complete clause venit Hesperus, confirms the independence of the first short clause. We can also take capellae as an appositive defining the noun saturae - the goats are the satires. All three senses are active, and yet all but the adjectival one are deniable, in case some over-anxious authority should accuse Virgil of writing satires to attack the powers that be- "Satires? Whatever gave you that idea? I'm talking about well-fed she-goats." Virgil prepares us well for this occurrence by using a form of capella in the Eclogues at line-end twelve times before this one. The second occurrence in Eclogue 1.74-Meliboeus, leaving for exile, says: "ite meae, quondam felix pecus, ite capellae"-is similar to the last line of the collection, but the similarity itself, by its difference, sets us up for the pun and the syntactical wizardry later: meae can only be adjectival, a possessive pronoun anticipating in gender, case, and number its noun, the feminine vocative plural capellae, and quondam felix pecus is not a clause, but an anticipatory appositive of capellae. A literal translation will make this clear: "go my, formerly happy flock, go she-goats." So this sentence is constituted of a single clause, not three independent ones.

But what could the poet mean by bidding his satires to go home? From our discussion of Eclogues 1 and 9, we might think "home" to be, in the first place, the mind and heart of a young prince in need of instruction, and beyond him, of all who can read and comprehend the subtle poetry. And the coming of the night-star Hesperus can suggest, in the context of the civil wars and the demise of the Republic, something more deeply to be mourned 
than nightfall, especially as it occurs in the last line of the collection. The lines just before it have struck an ominous note:

Surgamus: solet esse gravis cantantibus umbra, iuniperi gravis umbra, nocent et frugibus umbrae. Let us arise now, as shade is always grievous to singers; grievous the juniper's shade, and the shades do harm to the produce.

Umbra, umbrae, gravis, thrice one somber word and twice the other appear. The shade of civil disturbances is fatally grievous to such "singers" as Cicero, Brutus, and Cinna, and hardly less so to the entire culture of argument, poetry, and song. The shade of the juniper, a close relation of the funereal cypress, points to grievous death and desolation, especially since the word umbra, like shade in English, can mean the ghost of a dead person. And the many kinds of shade devastate the necessities of physical as well as spiritual life. Then the last line constitutes a sort of "envoy" to the whole collection.

The closest I can come to rendering this line in hexameter verse is as follows:

Go home, satires, the Night-Star comes, go satisfied, she goats.

This attempt to capture the play on words works only in part, but it may help clarify my explanation of a pun and a riddle of syntax that a literate Roman could have apprehended instantly. The treatise on rhetoric, Ad Herennium, attributed to Cicero but probably by a contemporary of his, includes a long and elaborate passage, IV.XXI.29-XXIII.32, on paronomasia, punning, and its uses, but this example is even better than the ones quoted there, as it does not require a change of letter or of vowel-quantity. I think the close attention worthwhile, because this significant word in the most prominent place in the collection, the final line, can make us revise our whole sense of what Virgil is essaying. Though we must remember that a satura was not necessarily invective-saturae, including those of Lucilius and Horace, could include a variety of subjects and approaches, rather as eclogae, selections, could-they are often "satirical" in the sense of critical, as we have seen with regard to Horace's epode and satire and to Virgil's first and ninth eclogues, and as we shall see as we consider the fourth.

Even for those who take it seriously as a prophecy, this eclogue poses a puzzle from the start: what wonderful Boy was it whose coming was supposed to transform the world into a new golden age? (See the full 
discussion of the possible candidates in COLEMAN, 150-152.) In those trying times, no doubt, many people hoped that such a splendid prospect lay before them, after the violence, exhaustion and repression of the civil wars. But the improbability that Virgil himself entertained these hopes might have given commentators pause. Could a poet who was one of the great geniuses of all time have been so beguiled by mere hopes on the basis of cloudy ancient prophecy? Such a notion of Virgil defies all that we know of his grave insights into men and their motives. We have already seen how he engaged a very real problem of the present, the expropriation of farms and what it signified about the ruler and his relation to his people. Then too, by assigning a definite date to the coming of this boy-the consulship of Pollio, in $40 \mathrm{BCE}$-Virgil ensured that its falseness would be demonstrated. Indeed, if the poem was published in 37 , as many scholars believe, the optimistic prognostication had already been disproved: no marvelous Boy in a cradle dripping with flowers had appeared, and the prophet who foretold him would have been shown to be fanatical, fatuous, and wrong - but amusing in his wrongheadedness, an apt subject for an entertaining recitation.

From another point of view the improbability that it was meant seriously grows even stronger. Men in power do not prize prophecies concerning some newcomer who might supplant them. Christians should be especially sensitive to this side of the question: a famous and tragic passage of the New Testament recounts the so-called Slaughter of the Innocents by King Herod, after the Wise Men-Magi, Three Kings-came to him inquiring about the whereabouts of the one who had been born King of the Jews, and his own counselors told him that the place would be Bethlehem as foretold by the prophet Micah. When, warned in a dream, the Magi failed to report to Herod who the boy was, the king ordered all the children in and near Bethlehem under two years old to be killed (Matthew 2:1-18). No doubt Herod was fully justified, in his own eyes, in trying to eliminate this potential claimant to his power. Something quite similar almost happened in Italy, and to Augustus himself, as Suetonius recounts, chapter 94:

A few months before Augustus was born a portent was generally observed at Rome, which gave warning that nature was pregnant with a king for the Roman people; thereupon the senate in consternation decreed that no male child born that year should be reared; but those whose wives were with child saw to it that the decree was not filed in the treasury, since each one appropriated the prediction to his own family. (A note explains that a decree is not complete until it is so filed.)

Whether this actually happened hardly matters: the report of it 
was known widely enough for Suetonius to have it in mind, and Octavian might well have wondered how close he came to being exterminated at birth. A poet might think twice before seriously emulating such a prediction.

Moreover, Augustus's own attitude toward miscellaneous prophecies appears in Suetonius, Chapter 31:

After he finally had assumed the office of pontifex maximus on the death of Lepidus (for he could not make up his mind to deprive him of the honour while he lived) he collected whatever prophetic writings of Greek or Latin origin were in circulation anonymously or under the names of authors of little repute, and burned more than two thousand of them, retaining only the Sibylline books and making a choice even among those.

It is not hard to infer that he considered such prophecies injurious to the civil peace and to his own status, as well as to religious orthodoxy. The loss of these effusions hardly ranks with the disappearance of the works of great writers, but if they had survived, Virgil's prophecy might well have been read in quite a different way, its parodic and satiric bent more apparent; perhaps he even borrowed some of his more extravagant predictions from them, and such allusions might have added to the amusement of his original audience. And though this conflagration of prophecies happened many years later, in 13 or $12 \mathrm{BCE}$, one cannot help wondering whether this very poem, with its unsparing satire on the pretentions of prophets, helped to plant the idea in Octavian's mind. At any rate, it certainly could have done so, for though it arouses both skepticism and laughter, it also demonstrates, by the history of its reception, how such prophesies can ring true even for sophisticated readers.

Virgil plants his tongue firmly in his cheek with the first line of the poem: "Sing we, Sicilian Muses, of subjects a little bit grander," paulo maiorem. It does not take long before we see that "paulo" greatly understates the case: the speaker aspires to the grandiosity of universal prophecy, not merely a somewhat less pastoral subject. In fact the tone then achieves what is characterized in the rhetorical treatise Ad Herennium (mentioned above) as the swollen style, in which "turgid and inflated language often seems majestic" (Ad Her. IV.X.15). This would become apparent if the lines were read aloud, as they may well have been in the popular mimes that were constructed from these Eclogues. The alliteration in 1. 4, Cumaei, carminis; the resounding and rhyming "o" in 5, integro, ordo, continuing in Virgo, 1.6, where also we have alliteration with repetition, redit, redeunt, regna; in 1. 7, 8 , and 9 more of "o," caelo, alto, modo, puero, quo, toto, mundo, all go beyond inflectional necessity to onomatopoeic rodomontade, reaching an early climax in Apollo, 1. 10. (I have tried to represent this inflated rhetoric in my 
translation.) As with the Horatian satire on culinary refinement considered earlier, this parody must have appealed to Octavian: Suetonius tells us in Chapter 86 that he preferred a "chaste and elegant" style of speaking. The whole chapter makes it clear that he would have been sensitive to the extravagances of this "prophet"-he himself poked fun at such rhetorical excesses.

But those high-flying statements about what is presently happening - the boy is being born just now, modo, emphasized by iam (now, already) repeated four times - are subtly undercut by the futures we next hear: all these wonderful events will take place pretty soon, since Pollio has been chosen as consul (or perhaps is already serving). Only then will it all happen, and the months will proceed magnificently. This is just the beginning of an overall comic pattern of postponement. Anticipating that pattern also is the equivocation in ll. 13-14, reading as if the vestiges of our old error will perhaps have been wholly swept away-but if any remain, they, invalid and ineffectual (inrita), will free the earth from perpetual terror. I understand that most readers would paraphrase this as something like, "they will be rendered ineffectual, and so the earth will be freed from perpetual terror"; but the literal and more equivocal-even confused (how can ineffectual vestiges of error free the earth from terror?)-significance is important for the blatant contradiction to follow. Meanwhile the future envisioned for this boy is of the highest sort, receiving divine life and mixing with gods and heroes, seeing and being seen by them. Whether this glances ironically at the status Octavian was claiming as divi filius must remain ambiguous, but if it does, the next line about how the Boy will rule a world subdued or pacified (pacatum) by his father's manly strength, valor, virtue-the word virtus is loaded-must be equally ironic: Julius Caesar subdued whole regions, but he participated in a violent civil war and bequeathed discord, not peace, to his quarreling successors.

Of course the prophet cannot have the grown-up Octavian in mind; it must be a Boy still in his mother's womb, perhaps the son of the Pollio to whom the poem is addressed. But there is no warrant for the idea that a consul, for all his prominence, would father a divine son. Better perhaps, that of Octavia and Antony-but that supposedly peace-bringing marriage was still in the future (October, 40 ) at the putative time of this prophecy, which must be set either in 40 or earlier in 41; and of course any Boy to result from it would hardly be on the brink of birth. As for an issue of Octavian himself, his only child, Julia, was born still later, in 39 . What frustration, to have no clear candidate! But of course that is the point. Nobody can hold a prophet responsible for a mistake, if he does not precisely identify the wonderful Boy. Nor can he be held guilty of lèse-majesté for mere ironic suggestions 
as to the identity.

Early hints that pigs may be trying to fly, as suggested in our own jocular adynaton "And pigs will fly" to refute an extravagant assertion, come in the next lines, which describe the child's first small presents. Yet it is unclear why ivy wandering everywhere should be impressive, on the one hand, or delightful, on the other. The Boy may be pleased by colocasia-if he knows what it is; few of his contemporaries would have, as this seems to be (according to the standard Latin Dictionary of Lewis and Short) the first use of this word, which means "an Egyptian bean ... growing in the lakes and marshes of Egypt ..." Could it therefore hint at that child who might more plausibly encounter such beans, the one which Cleopatra of Egypt by Octavian's partner Antony was expecting? After all, Antony too was attempting to subdue and pacify the world - on his own terms - and his child would be mixing with the enthroned gods of Egypt. As far as known pregnancies go, this is the one that best fits the putative date of the poem with fair exactitude. But far be it from a Roman poet to point openly to such an untoward Egyptian outcome. Yet what Boy could fail to like such a plant, especially when mixed with acanthus, which itself could be the acanthus we know, bear's foot, or as in Virgil's own Georgics 2.119, yet another Egyptian plant, a thorny acacia? But if he delights in beans and thorns, the wonderful infant may not care much about some of the other gifts, for example, those capellae, she-goats, that all of themselves bring home udders swollen with milk, the same joke as in Horace's poem-a normal countryside occurrence spoken of as extraordinary. Or herds that do not fear huge lions, an equally remarkable eventuality in an Italy where wild lions, if they ever existed, have long been extinct. But perhaps our mysterious infant, unlike ordinary ones, will enjoy having his crib pour flowers upon him-finally an unequivocal adynaton - and rejoice in the death of snakes and plants that deceive with their venom. Whether the availability of an Assyrian balsam-bearing plant, the amomum, to the multitude (vulgo) will give him pleasure must remain in question. Not incidentally, this word, like colocasia above and sandyx below, exemplifies one feature of the swollen style, "when a thought is expressed either in new or in archaic words"-thus sounding "more impressive than the theme demands" (Ad Her. IV.X.15). Suetonius tells us (Ch. 86) that Augustus himself sought to avoid, "as he himself expresses it, "the noisomeness of far-fetched words."”

Even more supposed marvels will appear once the Boy is able to read the praises of heroes and about the exploits of his father (Julius Caesar? Antony? Octavian himself?), and know what valor or manhood (virtus again) might be. And as with those milk-laden capellae, a listener may wonder 
just when and where the plain did not gradually turn yellow with grain at harvest-time. He might be less than enthusiastic about gathering reddening grapes from the uncultivated thorns where they will be hanging, and think that present arrangements for obtaining honey are superior to scraping honeydew from the hard trunks of sweating oak trees. Horace's golden land is more convenient in that respect, with its natural hives in hollow ilex trees.

But wait! Those old errors have not disappeared, after all: some few vestiges will remain, and they will cause us once more to endure the perils of sea-trade, to defend cities with walls, to plow the soil laboriously, to endure another voyage of the Argo, to see another heroic Achilles at Troy. We can understand that a prophet might want to hedge his bets, postponing the fulfillment of his prophecy to an indefinite future; but this one does so with such a vengeance as to leave us gasping. All these epoch-making events, which originally took place over the course of centuries, are to happen this time in the dozen or so years between the boy's childhood and his early adulthood, which comes in the next section of the poem.

Here pigs begin to fly in earnest. No trade will be needed, once the boy is confirmed in maturity, because every land will bear everything. No harrowing, weeding, or pruning will be needed. The sturdy plowman will free the oxen from their yokes. The last and therefore climactic blessing is that wool will not deceive with various colors, that is, be dyed. Instead we will be seeing rams with alternating purple and yellow fleeces-nature's own light-show-prancing in the pasture, and lambs wearing scarlet, sandyx. Only a literal reading, as in my translation, gives full value to this comically preposterous consummation-not rams of various colors, but rams changing colors. One might wonder whether garments made from such marvelous wool will continue to change color as they are worn!

Here finally even some of the commentators who see nothing funny about Virgil's prophecy begin to feel some unease. Thus remarks T. E. Page (VIRGIL, Bucolica et Georgica, 129): "There is only a step from the sublime to the ridiculous, and Virgil has here decidedly taken it"-not caring to notice that the poet has gone from one species of ridiculous, a repeated and drastically speeded-up history, to another. Thus Paul Alpers, after noting this and other examples of puzzlement about these lines, says, "It seems to me that something has gone awry in Virgil's pastoralism here (p.185)," and after an involved consideration of other "explanations" of this frivolity, concludes by agreeing with Page. He is also sensitive to other problems with the tone of this and other passages, but like other critics is so dominated by his solemn reading that he cannot put two and two together. Perhaps this is understandable; those other problems might be explained as matters of rhetorical exaggeration (the condensed repetition of history) 
or pastoral convention - though, in my view, not at all satisfactorily. But rams changing color from purple to yellow and spontaneously scarlet lambs fit only a satirical reading of the whole poem, and even for those who have not already realized what the poet is doing, they should cast their variegated illumination on the other preposterous features.

If for such listeners who can share Virgil's joke the comic pigs are flying wildly by this time, the speaker himself feels unquenched enthusiasm for this future, and he envisions the Parcae, the Fates, together with the unchanging will of the Fates-notice the egregiously "swollen" doubling of the idea-bidding their spindles to bring on such ages. And he turns to the wondrous Boy to bid him come soon, again with as much bombast as he can muster, climaxing in "great Jove's magnificent increase" and three lines evoking nature trembling and exulting over the great event, even though it is yet to occur (11. 48-52).

Despite this delay, the last sections give us a crescendo of comically brilliant extravagance. First the poet hopes for a long life and boasts of the excellence of the poem he will hypothetically make, if he survives long enough, in celebration of the hypothetical Boy's hypothetical exploits, and spends five inflated lines asserting his prospective superiority to the greatest poets-Orpheus, Linus - he can think of, even if they are supported by the very gods of poetry, Apollo and the muse Calliope. The near repetition of 1 . 58 in 1.59 might well have made his listeners break into loud guffaws at his assurance of conquering Pan with Arcadia judging.

But he rebounds from such laughter with even funnier lines, as he urges the Boy to start now, to recognize his mother with a smile, that mother who has born ten months of long discomfort-these menses recalling, but very different from, the magni menses early in the poem (1.12), which were confidently said to be about to begin, whereas the repeated imperative incipe $(11.60,62)$ to the fetus here sounds like an entreaty, as if the speaker is afraid that even this long pregnancy may not be over. The climax comes when he escalates the suggested smile by implying that if the boy is among those who do not laugh at their parents he will have no part in the feast of a god or the bed of a goddess. For risere plus accusative-parentes - means "mock, laugh at," and Virgil's joke, added to the extravagance of the threat, may be that his "prophet" is ignorant of this idiom and thinks he is just repeating his suggestion of a smile (risere with the dative means "smile at"; see my note on text and translation below.) The boy may get some comfort in the face of this dreadful prospect from the assurance that, unlike Herakles in Odyssey 11.601-626, who won immortality and the goddess Hebe as his bedmate only after great labors, merely mocking his parents will suffice for him. Yet all witnesses of childbirth know that neonatal derision is far less 
likely to happen than those twelve superhuman labors.

This ludicrous concluding threat might have alerted commentators, if no other absurdities of the prophecy had, that this was all an elaborate joke, though one with quite serious import. Through laughter, Virgil strongly implies a point rather like that of Horace in the epode we examined, one important at any time in history, but especially crucial in an age that experienced such terrible crises of civil discord and irregular governance: our wishes for a Savior, or for an age in which all our problems will be solved, are as illusory and distracting as our wishes for a Big Rock Candy Mountain, a Pays de Cocagne, Elsewhere. We cannot extricate ourselves from the labors and pains of life by projecting a golden age in the future, any more than we can escape from the evils we have caused by abandoning our city to the wild beasts in the hope of finding a better place. In particular, the work of governing will not be accomplished by a superman, but by a ruler, or a republic - Virgil and Horace may well have entertained hopes for the reinvigoration of that ancient and hallowed form of government, hopes shared by Augustus himself, or so he said-through hard work and deep understanding of the realities of life, farming, trading, defense.

For the most important of all his readers, Octavian, the veiled allusion to his claim to quasi-divinity as divi filius - the Boy will mingle with gods and heroes - in the context of this inflated prophecy might have discreetly suggested the questionable utility of assigning too much value to that status, so giving him a lesson he could learn without taking offense, as we saw with the other two Eclogues. The lesson is reinforced at the end: the satiric exaggeration of what the wonderful Boy might expect if he smiles or laughs at his mother or parents-banquets with gods, the bed of a goddess - may have allowed Octavian himself to laugh at the idea of such "godhead" without feeling under personal attack, all the more easily since in the previous passage Virgil has lampooned his own pretensions as a poet. Perhaps Octavian's laughter at these extravagances helped prepare the way for the ostentatious modesty he would display even after he became Augustus: it was better policy to downplay his status, by refusing triumphs and celebrations of welcome when he returned from abroad (again Suetonius has much to say about this) than to insist on it and be either envied or laughed at.

Virgil also debunks those who claim superior insight into what we need or what we can have, as this "prophet" contradicts himself (e.g., about the disappearance of our old errors), makes forecasts preposterous (centuries of history to be rerun in a few years) and trivial (grain turning yellow) and ludicrous (wool changing colors), boasts of his superiority (his hypothetical victories over Linus, Orpheus and Pan for hypothetical poems celebrating 
hypothetical achievements) and shows himself in general a self-deluding fool or an enthusiastic charlatan or both.

In fact, once the poem's actual drift is clear, it becomes hard to understand how it could have been taken seriously as a prophecy, and how commentators can still take it so. It is true that humanity loves prophets so much that it believes them even after they have been proven drastically mistaken. A major example is Jesus, who says, in Mark 9:1, "Verily I say unto you, That there be some of them that stand here, which shall not taste of death, till they have seen the kingdom of God come with power" (cf. also 14:62, MATTHEW 26:64), and he exhorts the disciples to be ready. Yet the failure of this prophecy to materialize had little or no effect on the success of Christianity. A more modern example is the self-proclaimed prophet Joseph Smith, who was sure he was living in the latter days and expected the kingdom of heaven to come in his lifetime; yet despite this notable "mistake," the church he founded is still, almost 200 years later, flourishing strongly and respectably under the name of The Church of Jesus Christ of Latter-Day Saints.

Apart from such indifference to the failure of prophesies to come true, and aside from the literary obtuseness of commentators, a major part of the answer to the question why this one was received as a genuine attempt to foretell the future surely derives from our traditional sense of Virgil as an intensely serious poet who never smiles in his greatest poem, the Aeneid, as Homer does in both of his epics. How can we call "satire" anything written by such a poet? Even after I have shown that he himself calls them by that name in the last line of the collection, many will refuse to think of him so. One can detect this attitude in many solemn commentaries, which sometimes read almost as if Virgil came out of the womb determined to write the Aeneid and admired from the beginning of his career the brash, insecure, and callous young Octavian, at whose dictates Virgil's family farm was confiscated, and who consented to the humiliating death of a great man, his own advocate, Cicero, and the proscription of many notable Romans.

But more of the answer, I think, is to be found in Virgil's skill as a poet, so in control of his resources that the apparent solemnity of his diction and versification casts a light of deep seriousness over the most ludicrous assertions. We may think again of the "Swift" of $A$ Modest Proposal, in which earnest reasonableness of tone and argumentation never desert the speaker, despite the savage indignation behind what he says. If that is a triumph of "pure rationality" which readers must see through to absorb the "lesson" concerning the callous neglect of the Irish poor, so this satire is a triumph of the swollen style. But this one invites our laughter, and by laughing we 
learn to question the great claims it makes.

Paradoxically, the Prince (Princeps-first among equals) whom Maecenas's coterie of poets may have regarded as their most important audience seems to have learned the lesson of these and other such efforts well enough that his Principate-for Principatus, not Dominatus (absolute rule), was the name given the dominion of the Caesars - did usher in what for miserable mortals in an imperfect world was a kind of golden age, the Pax Romana, peaceful, flourishing, and cultured. Through his education he turned out to be perhaps even more wonderful than the Boy whose advent this prophet proclaims. But that outcome did not happen miraculously or by divine intervention: it required sustained and laborious devotion to the governance of a complex and unwieldy empire. Suetonius tells us that Augustus became just such a ruler, hard-working, innovative, attentive to the needs of his subjects and devoted to their welfare. Though many of the senatorial party never forgave him for subverting the Republic while keeping its forms, he was loved by most of his people, and the cruel excesses of his earlier years were almost forgotten in the adulation that attended his maturity and old age. And both Virgil and Horace could write admiringly of his achievements in poems that rank among the greatest of the ancient classics. 


\section{BIBLIOGRAPHY}

ALPERS, Paul. The Singer of the Eclogues: A Study of Virgilian Pastoral. Berkeley, 1979.

CAWLEY, A. C., ed. The Wakefield Pageants in the Towneley Cycle. Manchester, 1958.

[CICERO]. Ad C. Herennium de Ratione Dicendi. Tr. Harry Caplan. London and Cambridge, MA: Loeb Classical Library 403. 1954.

HORACE. The Odes and Epodes. Ed. with introduction and notes by Clement Lawrence Smith. Boston, U.S.A., and London, 1899.

. Odes and Epodes. Ed. with introduction and notes by Paul Shorey, rev. Shorey and Gordon J. Laing. Chicago, New York, Boston, 1919.

The Odes and Epodes. Tr. C. E. Bennett. Cambridge MA, and London: Loeb Classical Library 33, 1988.

Satires, Epistles, Ars Poetica. Tr. H. R. Fairclough. Cambridge, MA, and London: Loeb Classical Library 194, 1970.

JOHNSON, Samuel. Adventurer 92. Disponível em: < http://www.readbookonline.net/readonLine/29991/>. Acesso em: 5 ago. 2014.

HAMMOND, N. G. L.; SCULLARD, H. H. (Ed.) Oxford Classical Dictionary [OCD]. Second ed. Oxford, 1991.

POPE, Alexander. Messiah. In: BUTT, John. (Ed.) Poems. New Haven, 1963. p.189-194.

QUINTILIAN. Institutio Oratoria, Book 9.3.8. Ed. Harold Edgeworth Butler. Perseus Digital Library. Disponível em: <http://www.perseus.tufts.edu/hopper/text;jsessionid=C12EF15 381754B6936CEOCDC428EF8CE? doc $=$ Quint. + Inst. $+9+3.8 \&$ fromdoc $=$ Perseus $\% 3$ Atext $\%$ 3A2007.01.0065>. Acesso em: 5 ago. 2014.

SUETONIUS. Life of Augustus. In: The Lives of the Twelve Caesars. Tr. J. C. Rolfe, v. 1, p.122-287. . London and New York: Loeb Classical Library 31, 1914.

SWIFT, Jonathan. A Modest Proposal. In Louis A. Landa, ed., Gulliver's Travels and Other Writings. Cambridge, MA, 1960. 439-446.

VAN SICKLE, John B. The Design of Virgil's Bucolics. London, 2004.

VAN SICKLE, John B. Virgil's Book of Bucolics, the Ten Eclogues Translated into English Verse: Framed by Cues for Reading Aloud and Clues for Threading Texts and Themes. Baltimore, 2011.

VIRGIL. Aeneid 7-12, The Minor Poems. Tr. H. R. Fairclough. [Dirae 462-471.] Cambridge, MA, and London: Loeb Classical Library 64, 1986.

VIRGIL [P. Vergili Maronis] Bucolica et Georgica. With Introduction and Notes by T. E. Page. London, 1957.

VIRGIL. Eclogues, Georgics, Aeneid 1-6. Tr. H. R. Fairclough, rev. G. P. Goold. Cambridge, MA, and London: Loeb Classical Library 63, 1999 reprinted 2006.

. Eclogues. Ed. Robert Coleman. Cambridge, 1977.

With an Introduction and Commentary by Wendell Clausen. Oxford, 1994.

WARMINGTON, E. H. Remains of Old Latin, Vol 3: Lucilius, The Twelve Tables. Cambridge, MA, and London: Loeb Classical Library 329, 1938. 


\section{Note on the Texts and Translations}

All quotations of Latin texts are drawn from the Loeb editions listed in the Bibliography, and all translations are my own, using English accentual meters to represent the quantitative meters of the original Latin-dactylic hexameters for all except Epode 16, which is in the "second pythiambic strophe," dactylic hexameter plus iambic trimeter. The Loeb editions of Horace are those of H. R. Fairclough for the Satires and of C. E Bennett for the Epodes. For Virgil's Eclogues and Georgics, I have used the Loeb edition of H. R. Fairclough, revised by G. P. Goold. I reject Goold's transposition of 1.23 to follow 1. 20; it has no authority in the codices, and it obscures the erratic movement of this "prophet's" mind, which shows up elsewhere. I also disagree with his rejection of Quintilian's reading of 1.62 (qui; Goold follows MSS reading cui), saying that his "error . . . continues to mislead" - as if any modern scholar could have anything like the mastery of Latin of one of the most erudite men of his time, who spoke, read, and wrote Latin from his childhood. Moreover, Quintilian, a mere century after Virgil, surely had access to manuscripts of the Eclogues more reliable than our earliest ones of the fourth century, by which time less erudite copyists must have "corrected" what they saw as an error, qui, in earlier MSS., to cui. In fact Quintilian cites these two lines (Institutio Oratoria 9.3.8) as an example of the very thing Goold rejects, the passage from plural to singular. Wendell Clausen more sensibly notes (144) that "the passage from a generalizing plural to the singular is Greek," and gives examples; this is far from the only place where Virgil adopts a Greek idiom. My translation follows this reading, even though the result is at least as awkward in English as copyists must have thought it in Latin. I also accept parentes, the accusative plural, against commentators like Clausen who want to change it to parenti (introducing another plural-singular conundrum, plural qui smiling at a single parent): Quintilian supports the unanimous authority of the MSS, and to change it is to miss a Virgilian joke on this "prophet." The speaker (unwittingly perhaps, ignorant of the idiom?) escalates the unlikely smile he demands of the new-born infant in line 60 to an even less likely mockery of the parents-in Latin idiom, whereas with the dative rido means smile at, with the accusative it means laugh at, mock, deride. So in order to enjoy the privilege of a god's board and a goddess's bed the infant must begin by deriding his parents!

The metrical translations below succeed best when read aloud, even declaimed, as the originals were, to bring out the preposterous suggestions and promises of the epode and the "swollen" rodomontade of the eclogue, thus making them funnier and more entertaining. 


\section{Horace, Epode 16}

Now is a new generation by civil wars utterly worn out, and by her own strength Rome is ruining herself.

She whom neither the neighboring Marsi had power to bring down, nor menacing Porséna's brave Etruscan host, nor fierce Spartacus, nor rich Cápua's envious manhood, nor Gallic Allobrox, disloyal when rebellion rose, neither did Germany, wild with its blue-eyed youngsters, subdue her, nor Hannibal, to parents so abominable; we will destroy her, an impious, cursèd-of-blood generation, our soil again the savage beasts will occupy.

Then the barbarian victor-alas! - will stand on the cinders, the horseman scourge the City with resounding hoof, Quírinus' bones that are now well away from the winds and the sunbeams, shall he-a crime to see! - in arrogance disperse. Maybe - and this would be best - the whole state, or the part that is better, you seek to free yourselves from evil suffering?

Never could counsel be wiser than this of mine: just as the city of Greek Phocaéans, having cursed their country and gods of their fathers, abandoned them and their shrines to the boars and rapacious wolves to make their lairs, and took to flight, so do we go wherever our feet will convey us, or over the waves where Notus calls, or wanton Africus. Does this please you? Or who has better advice? With the omens propitious, why do we delay to board the ship?

But as to this let us swear: so soon as the rocks shall arise from the sea-deep, swimming, coming back will be no crime; nor will it trouble us, shifting our sails to return to our home, when the River Po shall wash the high Matinian peaks; neither when Apennine summits shall jut forth into the seabrine, and wondrous love shall mingle monsters in a strange novel desire, so that mounting on deer will be pleasing to tigers; and bashful doves will be debauched by lustful kites; 
nor will the credulous herd be fearful of loud-roaring lions; the goat, all scaly smooth, will love the briny sea. These, and whatever can serve to cut off any sweet homecomings, when we have sworn, let us, the whole great city, goor the part better than that unteachable herd-let the feeble and hopeless stay ensconced within their ill-starred beds! You in whom manliness reigns, put away your womanish wailing. and take to flight beyond the long Etruscan coast, for the encompassing Ocean awaits us: fields let us search out, the happy fields, the wealthy Islands of the Blest, there where yearly the earth unplowed yields Ceres' abundance, and vines unpruned are flowering incessantly, shoots of the olive that never deceives us are sprouting and growing, the dusky fig is decorating its own tree, honey is flowing from hollows of holm oaks, and shimmering water is leaping down from lofty hills on rustling foot. There do the she-goats come to the milk-pails ever unbidden, the kind and friendly herd bring swollen udders home, nor in the evening does any bear growl, circling the sheep-fold, nor does the ground swell up with vipers to a hill. Happy are we, who will marvel at more-how watery Eurus will never scrape the earth with too abundant storms, neither will fertile seeds burn up in fields that are dried out, for heaven's king so tempers both the rain and heat. Hither has strained no nautical pine with its Argonaut-oarsmen, nor has a shameless Colchian woman set her foot, hither Sidonian sailors have never been turning their yard-arms, and neither has Ulysses' much-enduring crew. Never contagion will injure the flock, and the violent fury of no malignant star will scorch the cattle-herd. Jupiter put these shores in reserve for a race of the righteous, the time that he befouled the age of gold with bronzebronze and then iron-and hardened the ages; from them is a lucky escape vouchsafed the righteous by a prophet-me. 


\section{Virgil, Eclogue 4}

Sing we, Sicilian Muses, of subjects a little bit granderbushes do not please all, nor tamarisks common and lowly; if of the woods we sing, let the woods be fit for a consul.

Now is the last age come of the song of the Sybil of Cumae, that great order of epochs is born all fresh and untainted. Now does the Virgin return, and returns the Saturnian kingdom, now a new progeny is dispatched from the highest of heavens. Now therefore, as is born that boy by whom first the iron race will expire and a race all gold will arise in the whole earth, favor him, chaste Lucina, for now holds sway your Apollo! You also-this glory of ages will start when you are the consul, Pollio, and the magnificent months will commence their procession; you being leader, if vestiges of our iniquities yet live, once extinguished they will free earth from perpetual terror. He will be granted the life of the gods and will look at the gods and heroes commingling, and he himself by them will be looked at; he will be ruling a world pacified by the strength of his father.

But as her first small presents for you, Boy, Earth will be pouring forth untilled, all over, valerian, wandering ivy, rare colocasian beans commingled with smiling acanthus. Home will the she-goats all of themselves be bringing their udders swollen with milk, and the cattle will feel no fear of huge lions; all of itself your cradle will pour forth flowers to please you. Venomous serpents will die; such plants as deceive with their poison also will die; all over Assyrian balsam will spring up.

But then, when you can read panegyrics of heroes and your own father's exploits, and can comprehend what manliness might be, little by little the plain will become all golden with soft grain, reddening clusters of grapes will hang from the untamed brambles; so will the tough-barked oaks sweat dew with the sweetness of honey. Yet some vestiges still will remain of our primitive error, which will incite us to try out Thetis' domain with our galleys, 
girdle our cities with ramparts, and into the earth plow furrows. Then will a second Tiphys arise, and an Argo, the second, carrying heroes selected, and there will be other wars also, and to the Troäd again will be sent a heroic Achilles.

Later, as soon as the strengthening years have made you a real man, then from the sea will the trader retire, no nautical pine will serve in the barter of goods; all things all lands will be bearing. Neither the soil will be suffering hoes, nor the vine any pruning; then too the robust plowman will loosen the yoke from his oxen; neither will wool learn how to deceive with varying colors, but in his pasture the ram himself will be changing his fleece, now pleasantly blushing to purple, and now to the yellow of saffron; so spontaneous scarlet will mantle the pasturing lambkins.

"Times like this," to their spindles the Parcae said, "do you quickly spin," with the steadfast will of the Fates in solemn agreement.

Come along now-for the time is at hand-to your glorious honors, dear offspring of the gods, Jove's own magnificent increase!

50 See how the whole world trembles with all its ponderous vaulting, earth and the vast expanses of seas and the fathomless heavens! See how all creation exults in the age that is coming!

Oh, that the uttermost part of a long life yet may remain for me, that the breath I have will suffice to recount your achievements! Neither would Thracian Orpheus defeat me in singing, nor mournful Linus, although near one were his mother, the other his father, Orpheus backed by Callíopè, Linus by handsome Apollo; even if Pan with Arcadia judging competed against me, even so Pan with Arcadia judging would say he was vanquished.

So start now, little boy, with a smile to acknowledge your mother, mother to whom ten months have brought long qualms of discomfort. So start now, little boy-they who do not laugh at their parents, no god deigns to have him at his board, nor in bed any goddess. 